\title{
Managerial Style - A Literature Review and Research Agenda
}

\author{
Kerstin Lopatta ${ }^{1}$, Sebastian Tideman ${ }^{1}$, Katarina Böttcher ${ }^{2} \&$ Timm Wichern ${ }^{2}$ \\ ${ }^{1}$ Department of Socioeconomics, University of Hamburg, Germany \\ ${ }^{2}$ Department of Economics and Law, Carl von Ossietzky University, Oldenburg, Germany \\ Correspondence: Katarina Böttcher, Ph.D. Candidate, Department of Economics and Law, Carl von Ossietzky \\ University, 26111 Oldenburg, Germany.
}

Received: November 28, 2018

Accepted: January 10, 2019

Online Published: January 17, 2019

doi:10.5539/ibr.v12n2p80

URL: https://doi.org/10.5539/ibr.v12n2p80

\begin{abstract}
This literature review provides an overview of existing studies in the area of managerial style and its effect on firms' strategic decisions and performance. It highlights which managers' characteristics have been considered as determinants for managerial style so far and provides potential avenues for future research. After analyzing the content of all articles that were published in seven top-tier journals in the area of finance and banking between 2000 and 2016, the articles on managerial style were included in this literature review and categorized according to the main manager characteristic of investigation. The paper illustrates how similar characteristics are measured differently, and how different measurements of manager's influence the managerial style-firm strategy relationship differentially. We provide avenues for future research in the area of managerial style, that is, future research may investigate board member's characteristics at a more aggregated level (board level). Also, future research may shed more light on the argumentation of whether managers' individual style influences the firm's corporate decision or whether managers endogenously choose the firm due to their individual characteristics that match with the firm's strategy and vice versa. This study is interesting for firms that aim to find a manager or director who fits well to its own strategy. Although there is a rapidly growing literature on managerial style, there is yet no literature review that analysis research themes and strings on managerial style in finance journals.
\end{abstract}

Keywords: managerial style; manager characteristics; upper echelon theory, managerial fixed effects

JEL Classification: M12, G20, G30 G34

\section{Introduction}

According to Richard H. Thaler, a major issue in research that involves humans in economics is as follows:

.....Instead of humans, the world described by economists in text books is populated by a species referred to as homo economicus but I like to just call them Econs. These Econs solve problems like a super computer, have the willpower of saints, are free of emotion, and have little regard for their fellow Econs. (Thaler, 2017)

Humans are considered as a species with the intelligence of a supercomputer and never-ending power of volition, free of emotions and powered by egotistical motives. These attributes exaggeratedly meet the assumption of a rational, utility-maximizing and perfectly informed agent in economic models (Bofinger, 2011). Even though literature in finance suggests models that help to explain corporate decisions and problems, such as the trade-off between internal or external financing, as well as information asymmetries between firms and the capital market (e.g., Miller, 1977; Myers \& Majluf, 1984a), some researchers state there is a lack of explanatory power in prior archival studies on firms' behavior and strategic decisions (Bertrand \& Schoar, 2003; Hackbarth, 2008). Traditional models alone cannot help to identify reasons for heterogeneous capital structures (Lemmon, Roberts, \& Zender, 2008). Bertrand and Schoar (2003) conclude there must be some other factors and models that cause and explain heterogeneous investment and financing decisions.

In the last two decades, an emerging strand of literature has focused on the managerial style that considers CEOs or directors as individuals that differ in regards to their individual skills, preferences, conviction and resources. Our study provides a literature review of studies in that area, namely on the relationship between managerial styles (CEOs' individual characteristics) and firms' strategic decisions as well as financial performance or firm value. ${ }^{i}$ In the last two decades researchers have raised the question of whether managers can individually 
influence a firm. Bertrand and Schoar (2003) refer to this influence as the so-called "Managerial Style".

Although there is a rapidly growing literature on managerial style, there is yet no literature review that analysis research themes and strings on managerial style in finance journals. Quite close to this goal is the study of Pugliese et al. (2009), who provide a literature review on the boards-firm strategy relationship. But as their main focus are the involvement of boards at an institutional level and not board member's characteristics, we believe to contribute to the finance literature considerably. In this paper, we shed light on what the main challenges and potential future opportunities are. In doing so, we focus on studies that investigate the link between the CEOs' managerial style and the firms' investment, financing and/or organizational strategy as well as the firms' financial performance. In detail, we review 106 peer-ranked articles that were published in seven top-tier journals in the area of finance and banking between 2000 and 2016. Even though we limit our review to finance and banking related top-tier journals, our study identifies research gaps and provides avenues for future research.

The paper is structured as follows. After a short introduction, we provide a brief overview of relevant theories and our hypothesis development in Section 2, followed by our methodological approach in Section 3. The main part of the paper is the review of prior research. The paper ends with a discussion section that includes a research agenda and a short conclusion.

\section{Theory and Hypothesis}

\subsection{Theoretical Background}

According to Bertrand and Schoar (2003), most finance and investment literature is based on a neoclassical perception of firms, whereby management teams are assumed to be homogeneous. In line with Thaler (2017), the underlying mechanism of a neoclassical theory sees the homo economicus as an axiom that is perfectly substitutable due to their rational decisions (Bertrand \& Schoar, 2003). In line with this, agency theory is based on the assumption that agents are interested in maximizing their profits. However, from an agency perspective, market participants are exposed to information asymmetries and agency problems that cause market imperfections and lead to investment inefficiencies (Hubbard, 1998; Stein, 2003). Referring to this, prior literature argues the heterogeneous behavior of firms is caused by different magnitudes and distinctions of corporate governance mechanisms (Shivdasani \& Yermack, 1999). Shivdasani and Yermack (1999) find that the CEO's involvement enables the CEO to follow his/her own interest, which is associated with poor corporate governance. Nevertheless, their study underlies the assumption that CEOs are homogeneous and do not differ in terms of skills, preferences and conviction. Even though literature in finance suggests models that help to explain corporate decisions and problems such as the trade-off between internal or external financing as well as information asymmetries between firms and the capital market (e.g., Miller, 1977; Myers \& Majluf, 1984), some researchers point out a lack of explanatory power in prior archival studies on firms' behavior and strategic decisions (Bertrand \& Schoar, 2003; Hackbarth, 2008). Moreover, traditional models alone cannot help to identify reasons for heterogeneous capital structures (Lemmon et al., 2008). Agency theory largely ignores the possibility that agency problems can vary on the individual level, including firms and CEOs (Yim, 2013). Consequently, there must be some other factors and models that cause and explain heterogeneous investment and financing decisions (Bertrand and Schoar, 2003).

In contrast to most prior theoretical models, Hambrick and Mason's (1984) "Upper Echelon" theory provides researchers with a theoretical framework for analyzing the role of a CEO's individual characteristics in the context of corporate decision-making. The Upper Echelons theory is based on two elements: (1) CEOs' strategic decisions depend on their individual interpretation of the situation; (2) the CEO's individual interpretation is a function of his or her background characteristics, such as experiences, personality and personal values (Hambrick and Mason, 1984; Hambrick, 2007). Hence, the CEO's interpretation of a situation is biased due to his or her personality and different CEOs would decide differently in equal situations. Consequently, the extent to which a CEO acts rationally is limited, as it depends on their personal perception. The process of strategic choices is presented in Figure 1. 


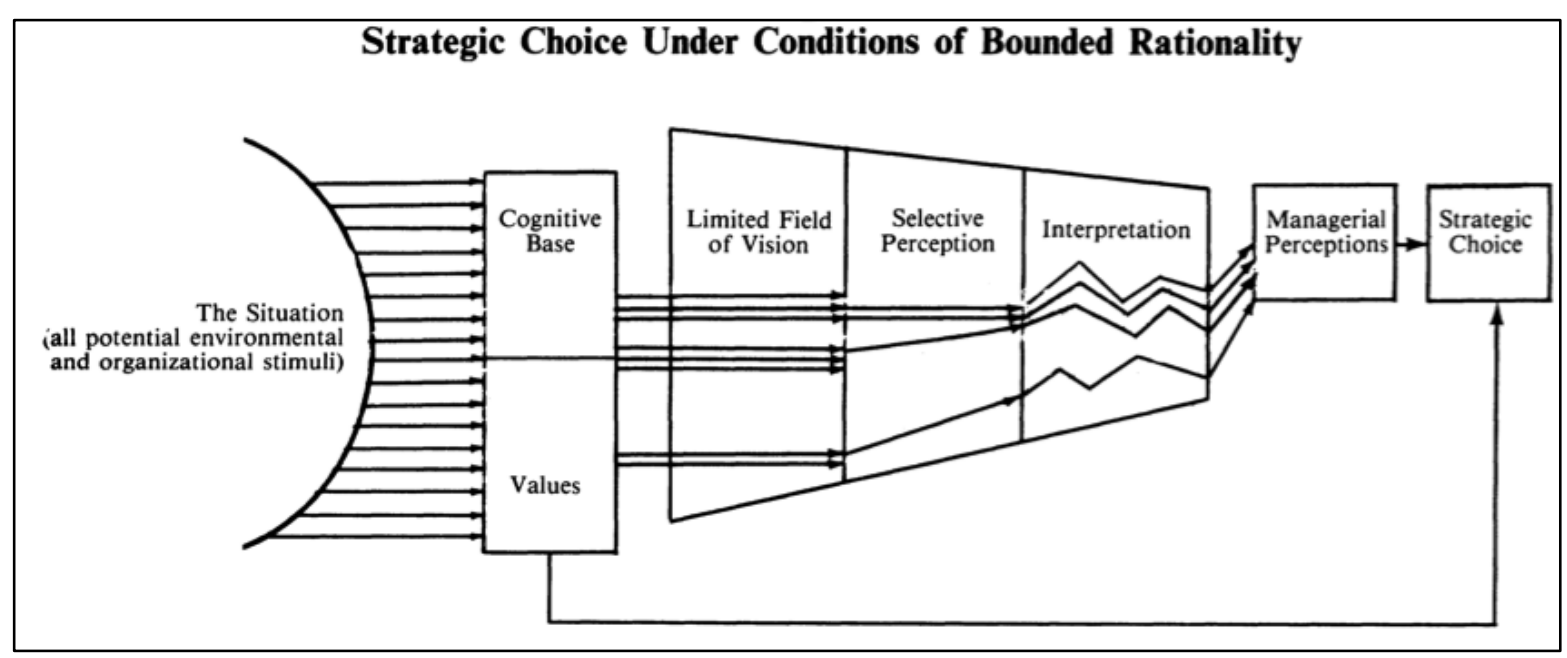

Figure 1. Theoretical Framework

Note. Figure 1 presents the theoretical framework provided by Hambrick \& Mason (1984): 195.

As presented in Figure 1, the situation ("all potential environmental and organizational stimuli") is processed based on the CEO's Cognitive Base and Values (Hambrick \& Mason, 1984). The cognitive base is the psychological dimension and difficult to observe. Therefore, Hambrick and Mason (1984) add on observable characteristics including age, professional experience (prior workplaces and different operational departments), education, socio-economic background and financial position (benefit plans and shareholding), as well as group-heterogeneity. The Upper Echelons Theory refers to the differences between members of the whole management team which is expected to have more explanatory power compared to focusing on a CEO as a standalone individual within a firm (Hambrick \& Mason, 1984). Indeed, the group's heterogeneity is relevant in psychological theories that consider the so-called "groupthink" effect. Thus, in homogeneous management teams, decisions can be made faster due to similarity in terms of characteristics such as age and education.

\subsection{Hypothesis Development}

Bertrand and Schoar (2003) identify two possible arguments as to why managerial styles do affect firms in the context of strong or weak corporate governance systems: on the one hand, in poor corporate governance mechanisms, the influence of individual managerial styles would be easier and stronger compared to firms with strong corporate governance, thus, firms' decisions can be influenced by individual managerial styles. On the other hand, it can be argued that the impact of managerial styles depends on the matching-quality between CEO and firm. Hambrick and Mason (1984) argue that firms benefit from management homogeneity in an economically stable environment. In contrast, heterogeneity would be beneficial for firms during times of change and upheavals, where heterogeneous discussions promote new ideas and innovation. Overall, we follow the on the Upper Echelons theory based argumentation (e.g., Bertrand and Schoar, 2003; Hambrick and Mason, 1984) suggesting differences in managers' cognitive bias and values affect their individual skills, preferences, conviction and resources which in turn also affect firm outcome. Referring to the question whether managers can individually influence a firm, referring to the so-called "Managerial Style", leads us to the following hypothesis:

\section{H1. Managerial styles are related to firm outcomes}

\section{Method}

\subsection{Selection of Journals and Papers}

In order to test this hypothesis, we examine the evolving literature on managerial style. Thereby, we only focus on peer-reviewed studies published in finance journals, regardless of their impact factor which is in line with other literature reviews (e.g., Seglen, 1994; Pugliese et al., 2009). As mentioned in the beginning of this paper, we focus on top-tier finance journals. We select all "A+"- and "A"- ranked journals based on recent journal rankings within the banking and finance category (e.g. the Financial Times 50 and the VHB_JOURQUAL 3 ranking of July 1st, 2017). We do not cover journals in the field of general, operational and strategic management or accounting journals due to capacity constraints of this literature review. Future studies may also identify research strings on managers in these journals. The distribution of papers across journals is presented in Table 1. 
Table 1. Distribution across Finance Journals

\begin{tabular}{lll}
\hline Journal & Rating & $\begin{array}{l}\text { Number of } \\
\text { Articles }\end{array}$ \\
\hline Journal of Financial Economics & $\mathrm{A}+$ & 34 \\
Journal of Banking \& Finance & $\mathrm{A}$ & 22 \\
The Journal of Finance & $\mathrm{A}+$ & 17 \\
The Review of Financial Studies & $\mathrm{A}+$ & 15 \\
Journal of Financial and Quantitative Analysis & $\mathrm{A}$ & 14 \\
Review of Finance & $\mathrm{A}$ & 2 \\
Journal of Financial Intermediation & $\mathrm{A}$ & 2 \\
\cline { 2 - 3 } & Total & $\mathbf{1 0 6}$ \\
\hline
\end{tabular}

Note. This table presents the number of papers per journal that were considered in this literature review. This literature review is limited to top-tier finance ("A+"- and "A") ranked journals based on recent journal rankings within the banking and finance category (e.g. the Financial Times 50 and the VHB_JOURQUAL 3 ranking of July $1^{\text {st }}, 2017$ ).

We do not include the Journal of Economic Dynamics \& Control and Journal of Money, Credit and Banking because they do not cover research on manager's characteristics. In the next phase, we searched for paper publications regarding managerial style by screening all articles in the selected journals. Instead of using an automated content analysis based on keywords, which is exposed to the risk of missing out important articles, we read at least all articles' abstracts and the introduction. This provides us with two advantages. First, this reduces the risk that we leave out important articles as it could occur when using an automated content analysis. Second, it enables us to classify and structure the articles according to their main subject of investigation. We limit the review of articles to the ones that document results or output arising from CEO characteristics (output side) or managerial styles, as, for example, effects on the firm's strategic decision or firm performance. Also, we exclude papers that do not document effects arising from CEO characteristics, but focus on the input side, such as bonus plans (Engelberg et al. 2012a; Graham et al., 2012). Our final sample results in 106 articles published in seven different finance journals from 2000 to 2016. The next subsection illustrates which CEO characteristics were analyzed in the above-mentioned timeframe and also serves as an overview of the main subjects of investigation that we include in this review.

\subsection{CEO Characteristics}

In order to analyze the evolving nature of studies on managerial style or firm performance, we review a set of 106 articles. According to the articles' main object of investigation, we find seven different leading characteristics of CEOs that were analyzed in prior literature. Table 2 presents the sample distribution of the number of papers on different characteristics that were assigned to the respective category. Two articles investigate and critically scrutinize the measurability of a CEO's individual impact, which is acknowledged in our research agenda (Section 5.1).

Table 2. Distribution across Categories

\begin{tabular}{lll}
\hline Category & CEO characteristics & Number of Articles \\
\hline$(1)$ & Demographic characteristics & 12 \\
$(2)$ & Management quality and reputation & 20 \\
$(3)$ & Professional and life experience & 16 \\
$(4)$ & Private behavior and political conviction & 8 \\
$(5)$ & Overconfidence and optimism & 20 \\
$(6)$ & Founder and successor & 11 \\
$(7)$ & Network relationships & 17 \\
$(8)$ & Research gaps & 2 \\
\hline
\end{tabular}

Note. This table presents the number articles that were assigned to the identified categories according to the main subject of the articles' investigation. In some cases, characteristics overlap with two or more categories. Nevertheless, all articles were categorized according to their main object of investigation. As presented in Table 2, the first category is demographic characteristics (1), which is the most accessible characteristic compared to other categories and includes age, gender and education. Management quality and reputation (2) represent the second characteristic. The third category, professional and life experience (3) shows the CEO's milestones and career steps achieved in his/her lifetime. As CEOs exhibit extensive curricula vitae and expert knowledge, there is a broad literature mainly focusing on effects of a CEO's finance and industry expertise. In contrast to professional experience, the next characteristic is private behavior and political conviction (4), which is less able to be influenced by the employer's incentive and control structures (Davidson, Dey, \& Smith, 2015). However, researchers argue that private behavior and political conviction is assignable to someone's professional life (Cronqvist et al., 2012; Hutton et al., 2014; Cain and McKeon, 2016). Another relevant characteristic for investment decisions and risk taking is overconfidence and optimism (5). Prior literature shows different approaches and models to measure these characteristics. When prior studies have analyzed the effects of family firms on firm value and performance, most studies focus on the 
question of whether a family or non-family business is more profitable. Furthermore, we sum up the literature on the effects of the founder and successor at board level (6) and effects of CEO's network relationships (7) on firm outcome which includes network resources and human capital.

Panel A of Table 3 presents the distribution of articles over the countries or origins and over time. Most articles are based on U.S. samples (77 articles). Thus, we review the following articles knowing that most of them are based on a sample of American firms, the American political environment and its board system. Therefore, the generalization of the results is limited to the samples' origins. Panel B of Table 3 shows that our timeframe of 2000 and 2016 is appropriate, as most articles have been published recently. Secondly, only nine out of 106 articles are based on financial institutions, which will be noted accordingly. Thirdly, 86 percent of all studies take empirical models into account. Another ten percent develop analytical models - but of these four also test their models empirically. The remaining articles are based on interviews, which combine interview with financial data.

Table 3. Sample Distribution

\begin{tabular}{|c|c|c|}
\hline \multicolumn{3}{|l|}{ Panel A: Distribution across countries } \\
\hline Country & $\begin{array}{l}\text { Number of } \\
\text { Articles }\end{array}$ & In percent $(\%)$ \\
\hline U.S. & 77 & 72.64 \\
\hline China & 5 & 4.72 \\
\hline U.K. & 2 & 1.89 \\
\hline Finland & 1 & 0.94 \\
\hline Russia & 1 & 0.94 \\
\hline Denmark & 1 & 0.94 \\
\hline Belgium & 1 & 0.94 \\
\hline Norway \& Sweden & 1 & 0.94 \\
\hline Belgium & 1 & 0.94 \\
\hline International sample & 13 & 12.28 \\
\hline Analytical studies only (no sample) & 3 & 2.83 \\
\hline Total & 106 & 100 \\
\hline \multicolumn{3}{|l|}{ Panel B: Publications per year } \\
\hline Year & Number of Articles & In percent $(\%)$ \\
\hline 2001 & 1 & 0.94 \\
\hline 2003 & 3 & 2.83 \\
\hline 2005 & 4 & 3.77 \\
\hline 2006 & 3 & 2.83 \\
\hline 2007 & 2 & 1.89 \\
\hline 2008 & 5 & 4.72 \\
\hline 2009 & 9 & 8.49 \\
\hline 2010 & 1 & 0.94 \\
\hline 2011 & 8 & 7.55 \\
\hline 2012 & 7 & 6.60 \\
\hline 2013 & 19 & 17.92 \\
\hline 2014 & 14 & 13.21 \\
\hline 2015 & 19 & 17.92 \\
\hline 2016 & 11 & 10.38 \\
\hline Total & 106 & 100 \\
\hline
\end{tabular}

Panel A of Table 3 presents the distribution (absolute numbers and percentage) of articles over the countries or origins of reviewed articles. Panel B presents the number of publications per year in the time frame of 2000 and 2016.

\section{Results}

\subsection{Demographic Characteristics}

In line with our hypothesis, most studies do find a significant relationship between managerial styles and firm outcomes. This will be illustrated in the context of demographic characteristics in the following. According to Hambrick \& Mason (1984), most studies provide evidence that older CEOs tend to be less aggressive in financial decisions and realize fewer acquisitions (Bertrand and Schoar, 2003; Yim, 2013; Jenter and Lewellen, 2015). Building upon the "Empire Building Theory" and the positive correlation between size and CEOs' compensation, younger managers benefit from acquisitions for a relatively long time frame (Yim, 2013). In a sample of Finnish banks, Kauko (2009) shows that cost-efficiency is at its optimum with CEOs at the age of 50. 
However, when CEOs grow older, incentives to realize new ideas and concepts decrease, which leads to a non-linear relationship between age and efficiency. Furthermore, they conclude that cost-efficiency is significantly lower in firms before a CEO retires.

Using MBA degree as a proxy for financial expertise, other studies analyzed the effects on the quality of financial decisions (Chemmanur \& Paeglis, 2005; Dittmar \& Duchin, 2016; Jiang, Wan, \& Zhao, 2016). According to Bertrand and Schoar (2003), firms with managers who hold an MBA degree appear to follow, on average, more aggressive strategies including higher investments and higher leverage and achieve a higher profitability. In a survey with $392 \mathrm{CEOs,} \mathrm{Graham} \mathrm{and} \mathrm{Harvey} \mathrm{(2001)} \mathrm{find} \mathrm{evidence} \mathrm{that} \mathrm{CEOs} \mathrm{with} \mathrm{an} \mathrm{MBA}$ degree use more sophisticated valuation methods.

In a Swedish and Norwegian study, Oxelheim and Randøy (2003) find that firms even adopt a CEO's Anglo-American background and incorporate it within the firm's extent and quality of corporate governance. This in turn attracts international investors and positively affects the firm's market value. However, some studies find a negative relationship between national diversity at board level and the firm's financial performance (Norway \& Sweden: Oxelheim and Randøy, 2003; Global: Mersland and Strøm, 2009; García-Meca et al., 2015). Other studies point out that CEOs overestimate their own capabilities especially in North American and European firms (cross-country study: Ferris et al., 2013). In this context, some studies document that especially male CEOs overestimate their own capabilities (U.S.: Barber and Odean, 2001; Huang and Kisgen, 2013; Global: Graham et al., 2013).

A review of finance-related articles on the link between gender diversity at board level and the effect on financial performance shows that results are inconclusive. ${ }^{\text {ii }}$ However, the majority of prior studies document a positive relationship (Mersland and Strøm, 2009; Strøm et al., 2014; García-Meca et al., 2015), while Adams and Ferreira (2009) document a negative relationship. The positive relationship can be explained against the background of the matching theory (both financial insitutions: Mersland and Strøm, 2009; Strøm et al., 2014): The high presence of female customers and the perception of women of taking care and responsibility for others reduces information asymmetries. Tate and Yang (2015) suggest an important externality to having women in leadership positions: "they cultivate more female-friendly cultures inside their firms". Also, firms with more female CEOs have less short-term liabilities (Graham et al., 2013), tend to realize fewer acquisitions as well as fewer issuances of debt instruments and at the same time positively affect the firms' cumulative abnormal returns (Huang \& Kisgen, 2013).

\subsection{Management Quality and Reputation}

For the CEO's reputation, most studies use the number of directorships as a proxy (Chemmanur and Paeglis, 2005; Chemmanur et al., 2009; Jiang et al., 2016; Lin et al., 2016). ${ }^{\text {iii }}$ The number of directorships implies the CEO's reputation including his/her talents and skills in an outside labor market (Fama \& Jensen, 1983; Lin et al., 2016). On the one hand, more directorships indicate beneficial characteristics, such as diversified experience as well as know-how and widely spread network relationships (Ferris et al., 2003; Perry and Peyer 2005; Jiraporn et al., 2009; Ahn et al. 2010). On the other hand, having more directorships also means more busyness, which can be associated with being "too busy to mind the business" (Ferris et al., 2003; Jiraporn et al., 2009). In fact, results are inconclusive: Ferris et al. (2003) find no significant relationship between busy CEOs and the firm's market value. Fich and Shivdasani (2006) find a negative relationship between busyness and board independence and the firm's market value. Jiraporn et al. (2009) mention a non-linear but convex relationship between attendance at board committee meetings and the number of directorships. Inconclusive results could be caused by a one-size-fits-all threshold of board attendance across all boards (Ahn et al. 2010). Also, differences may occur due to different samples or methodological approaches such as the use or omission of firm fixed effects (Cashman, Gillan, \& Jun, 2012). Indeed, smaller firms or Initial Public Offerings (hereafter: IPOs) benefit from busy CEOs, while bigger firms more or less suffer from the CEO's busyness (Graham et al., 2012; Field et al., 2013). When firm fixed effects are taken into account, Cashman et al. (2012) find a negative effect on the firm's market value and profitability, while Elyasiani and Zhang (2015) find a positive effect on EBIT, Tobin's Q and ROE in financial institutions.

In their event study, Perry and Peyer (2005) find that dependent directors positively affect the firm's reputation, and, in case of management turnovers, the manager's firm of origin achieves higher cumulative abnormal returns (CAR). In line with this, Lin et al. (2016) posit that reputable inside directors (dependent) can improve the quality of borrowers' financial reporting and reduce agency risk in loan contracting. However, results do not hold for independent non-executive directors. In a natural experiment, Falato et al. (2014) analyze how the death of 557 independent directors affects the stock market and find a negative reaction for all firms where the manager 
served at board level before he died. In contrast to most other studies beforehand, Falato et al.'s (2014) approach reduces the risk of endogeneity for the business hypothesis as the deaths are exogenous shocks to the firms.

In order to proxy for management quality, Rahaman and Zaman, (2013) base their analysis on a management-type score provided by Bloom and van Reenen (2007) and find that banks value management quality and provide firms with better credit conditions in the case of higher management quality. Others use the lower stock price volatility (Pan et al., 2015) or positive market reactions to disapproved high cost acquisitions or fusions (Jacobsen, 2014). Kaplan et al. (2012) use a factor analysis based on the expertise of consulting firms. For their study on firms in emerging countries, Cornelli et al. (2013) took the verbal CEO evaluation from monitoring reports provided by the European Bank for reconstruction and development. Even though methods differ across studies, most prior studies document that management quality is beneficial (Chemmanur and Paeglis, 2005; Kaplan et al., 2012).

Chemmanur et al. (2009) suggest a number of variables to quantify the management quality and show that firms with high management quality and reputation pay lower dividends, have lower leverage and have better access to equity capital. This is supported by Bhagat et al. (2011), who use the CEO's tenure of office and compensation as a proxy for management quality. Pan et al. (2016) presents a "CEO Investment Cycle": disinvestments are rare in the beginning of a CEO's career but increase with higher incumbency.

\subsection{Professional and Life Experience}

A broad strand of literature mainly focuses on the effects of a CEO's finance and industry expertise. In general, a CEO passes several milestones and career steps, which is why CEOs are age, on average, 50 years or older (Chemmanur et al., 2009; Kaplan et al., 2012; Custódio and Metzger, 2014; Graham et al., 2015; Pan et al. 2015; Dittmar and Duchin, 2016). Finance literature defines expert knowledge in a certain industry, when someone has gained experience in leading positions in that specific industry (Custódio \& Metzger, 2013; S. Huang, 2014; Wang, Xie, \& Zhu, 2015). CEOs have financial expertise, when they dispose of working experience in leading positions in the financial sector or finance-related fields such as auditing, accounting or leading academic positions (Güner et al., 2008; Custódio and Metzger, 2014; Minton et al., 2014). However, researchers should keep in mind that financial experts at board level could follow banks' interests rather than the firm's interests, which would lead to less favorable financial conditions (Güner et al., 2008). Supporting this argument, some studies document that firms with financial experts tend to have a higher financial leverage (Graham et al., 2013; Custódio and Metzger 2014). Additionally, Custódio and Metzger (2014) find a less favorable financial structure, such as leverage combined with low liquidity and more share repurchases. Based on their survey with CEOs and CFOs, Graham et al. (2015) conclude that managers do not delegate financial decisions when they exhibit financial knowledge themselves. In contrast, some researchers document positive effects of financial expertise on innovative capacity and acquisitions (Celikyurt, Sevilir, \& Shivdasani, 2014) or higher stock returns (financial institutions: Adams and Jiang, 2016).

When experiences are analyzed in the context of a financial crisis, results differ as follows: Minton et al. (2014) show that banks with independent board members with financial expertise are more willing to take risks. However, this led to a weaker financial performance during the financial crisis in 2007 and 2008 compared to firms without financial expertise at board level. Dittmar and Duchin's (2016) results imply crisis experience reduces the willingness to take risks, which the authors interpret as a learning effect. Apart from Custódio and Metzger (2014), who investigated effects of financial experience on innovation, marketing and labor, most studies focus on the effect of financial expertise on financial performance. However, empirical evidence on non-financial decisions is rare.

In the context of acquisitions, financial expertise seems to be beneficial (Custódio \& Metzger, 2013; Wang et al., 2015). CEOs with industrial expertise increase the monitoring effectiveness and market-related financial performance of the purchasing firm (Wang et al., 2015) and pay a lower premium because of a better negotiation position, especially in industries with high information asymmetries (Custódio \& Metzger, 2013). Specifically, the probability of firms acquiring other capital market-oriented companies is 4.5 times higher when their board member has been working in that specific firm (Rousseau \& Stroup, 2015). In line with their "divest-for-better-match" hypothesis, Huang (2014) finds that CEOs divest divisions that operate in industries in which they have less experience which leads to a better CEO-firm match and a better operating performance. According to Xuan's (2009) bridge-building hypothesis, CEOs assign more capital budget to divisions where they are less experienced in order to elicit cooperation from powerful divisional managers. Their results show that having a specialist CEO negatively affects investment efficiency after a turnover. In contrast, Dass et al. (2014) find that CEOs who operate in the upstream/downstream industries of a firm have a positive effect on the 
firm's value/performance. In sum, general management skills are more valued than industry expertise (Bertrand \& Schoar, 2003; Kaplan et al., 2012).

Custódio and Metzger $(2013,2014)$ argue that results of prior studies are limited to the extent that industry expertise could indicate that CEOs have better network relationships. As know-how and expert knowledge as well as network relationships are two important dimensions of a CEO's human capital, Custódio and Metzger $(2013,2014)$ argue it is worth distinguishing between those characteristics.

Other studies show that CEOs' work experience abroad is positively related to a higher ROE, audit quality and international acquisition activities (Giannetti, Liao, \& Yu, 2015). In case of repetitive acquisitions, CEOs who have worked overseas are able to realize learning effects so that the time between acquisitions can be reduced (Aktas, Bodt, \& Roll, 2013). Also, personal life experience can be relevant, as Benmelech and Frydman (2015) find CEOs with military experience reduce the probability of fraud in accounting, invest less, reduce leverage and show strong leadership in economic crises. However, Malmendier et al. (2011) show that CEOs with military experience in the Second World War undertake more aggressive financial decisions, including higher leverage.

\subsection{Private Behavior and Political Conviction}

In contrast to professional experience, private behavior seems to be less influenced by the employer's incentive and control structures (Davidson et al., 2015). Cronqvist et al.'s (2012) consistency theory suggests that private behavior is assignable to professional behavior as it is assumed that humans make the same decisions in different situations. Prior studies find a positive correlation between the level of a CEO's private debt level and the firm's indebtedness ratio (Cronqvist et al., 2012; Hutton et al., 2014; Cain and McKeon, 2016). Cain and McKeon (2016) find that CEOs with pilot licenses are more venturesome and risk-taking, which also affects the risk taking at firm level. Furthermore, Davidson et al. (2015) show that a CEO's fragility in terms of consumption of luxury goods is related to a lower number of false balance sheet statements and intentional balance sheet manipulation is affected by the CEO's or CFO's private infringements (traffic or violent offences). Mironov (2015) presents evidence that having a corrupt management is positively correlated with falsified incomes and lower accounting quality in Russian firms. Firms with CEOs who used to backdate options in the past are more likely to face fraud trials (Biggerstaff et al., 2015).

When political convictions have been examined, most studies define the tendency to a political direction based on charity for a certain party (Di Giuli \& Kostovetsky, 2014; Hutton et al., 2014; Lee, Lee, \& Nagarajan, 2014). On the one hand, firms with Republican CEOs exhibit lower debt-equity ratios and lower investments in Property Plant and Equipment (hereafter: PPE) as well as in Research and Development (hereafter: R\&D) compared to firms with Democrats as CEOs (Hutton et al. 2014). Based on the approach of Cronqvist et al. (2012), Hutton et al. (2014) show that Republican CEOs are more risk-averse and have a lower private debt ratio than Democrats. On the other hand, firms with Republicans as CEOs undertake less investments for Corporate Social Responsibility (hereafter: CSR) activities (Di Giuli \& Kostovetsky, 2014). When the political convictions of a CEO and an independent (non-executive) director concur, monitoring effectiveness is lower, which results in a lower ROA, lower probability to replace a low-performing CEO and a higher probability to face financial fraud trials (Lee et al., 2014).

\subsection{Overconfidence and Optimism}

Malmendier and Tate (2005) present empirical evidence on the relationship between overconfident CEOs and firms' behavior. They find a "better-than-average effect", which suggests that individuals overestimate their influence on future events and their accuracy of forecasts ("narrow confidence intervals"). Also, they evaluate their skills above average, which refers to the so-called self-attribution bias (SAB). We identify two main strategies to proxy for overconfidence and/or optimism that have been used in prior literature: (1) observation of the CEO's private share portfolio and (2) news-coverage or reporting about a manager. The latter proxy is evaluated based on words that were used in the context of CEOs and their actions in economic-related journals or reports (Malmendier and Tate, 2008; Hirschleifer et al., 2012; Ferris et al., 2013; Banerjee et al., 2015). The first strategy indicates a CEO's risk-aversion. Malmendier and Tate (2005) would expect a risk-averse CEO to exercise options at an early stage once the shares reached a certain level and would have a diversified portfolio. ${ }^{\text {iv }}$ The opposite behavior would be interpreted as overconfidence because CEOs hope for increased share prices. When prior studies derive the level of overestimation from the first observation strategy, the majority include Malmendier and Tate's (2005) "holder 67"-indicator (e.g., Malmendier and Tate, 2008; Malmendier et al., 2011; Hirschleifer et al., 2012; Andriosopoulos et al., 2013; Deshmukh et al., 2013; Bouwman, 2014). ${ }^{\mathrm{v}}$ This indicator classifies a CEO as overconfident, once he or she holds shares, even though the share price increased by 67 
percent. Bouwman (2014) bases her study on the approach of Malmendier and Tate (2005) but uses this proxy for the CEO's optimism only. All in all, empirical research is still lacking a valid measurement of overconfidence and confidence of managers, as there is no one-size-fits-all indicator.

In contrast to the first strategy, the second proxy does not allow researchers to distinguish between optimism and overconfidence but does show how a CEO is being evaluated by a third party (Malmendier and Tate, 2008; Ferris et al., 2013). In contrast to the strategies mentioned above, Kim (2013) develops an approach to directly measure the SAB by analyzing the CEO's language in TV interviews. The more personal pronouns are used in combination with positive events, the higher Kim assigns characteristics such as optimism and overconfidence to a CEO. Similarly, Aktas et al. (2016) utilized this measure to define the CEO's level of narcissism. The above above-mentioned SAB leads to two hypotheses in subsequent studies (Malmendier and Tate, 2005; Malmendier et al., 2011): (1) Managers who overestimate their own abilities systematically overestimate returns of investment projects, or (2) evaluate the cost of external capital as excessive.

In this context, overconfidence would be beneficial for growing firms as they would benefit from more risky but innovative investment decisions made by overconfident CEOs (Hirschleifer et al., 2012). The second assumption predicts that managers overestimate their cash flows and therefore require a lower risk premium on interest rates for debt capital compared to a rationally reasonable risk premium (Malmendier et al., 2011). Indeed, overconfident CEOs often refuse external capital and depend on internal financial resources, which leads firms to be more sensitive to cash flows and investments (Malmendier and Tate, 2005; Campbell et al., 2011; Banerjee et al., 2015). In the case of insufficient internal financial resources, overconfident CEOs do have higher debt ratios (Malmendier et al., 2011; Ho et al., 2016) and do pay less dividends in order to retain earnings (Deshmukh et al., 2013) but also intensively buy back share programs because they consider their equity capital as undervalued (Andriosopoulos et al., 2013).

When researchers focus on the effects of overconfidence on acquisitions, results are inconclusive. Overconfident CEOs often fund acquisitions with cash (Malmendier and Tate, 2008; Ferris et al., 2013; Kim, 2013) and overconfident CEOs realize a higher number of acquisitions compared to firms with non-overconfident CEOs (Malmendier and Tate, 2008; Ferris et al., 2013; Graham et al., 2013; Kolasinski and Li, 2013). However, overconfident CEOs reduce their willingness to take risks when they have experienced higher losses in their portfolio (Kolasinski and Li, 2013). Adam et al. (2015) analyze the hedging-behavior of American gold mining companies and find that managerial overconfidence also affects corporate risk management decisions. However, Banerjee et al. (2015) observe overconfident CEOs reduce risky behavior ex post external events such as the Sarbanes-Oxley Act (SOX).

Focusing on narcissism, Aktas et al. (2016) show that when the CEOs of both negotiation parties are narcissistic, the probability of a successful acquisition is low. It is the question, whether results are similar for acquisitions under the control of overconfident CEOs on both sides. Malmendier and Tate (2008) show that acquisition announcements of overconfident CEOs lead to negative capital market reactions. Kim (2013) supports this evidence but only for CEOs who are extremely overconfident. Analytical studies predict that a moderate level of overconfidence and optimism maximizes firm value (Goel and Thakor, 2008; Hackbarth, 2008; Campbell et al., 2011; Gervais et al., 2011). Nevertheless, an optimal extend of overconfidence depends on the firm's size and growth strategies (Gervais et al.'s (2011). Though, overconfident CEOs are expected to operate in growth companies due to their high performance-based compensation. This perception is supported by Hirschleifer et al. (2012), who show that overconfident CEOs are highly innovative due to their higher willingness to take risks.

\subsection{Founder and Successor}

In this chapter, we summarize studies that investigate how family firms and CEOs who are founders or successors affect firm value and financial performance. The characterization of a firm as a family business is based on elements such as ownership, control and management (Villalonga \& Amit, 2006). Researchers highlight this area because most of them expect to find reduced agency costs between the owners and the management in family firms compared to non-family businesses (Villalonga and Amit, 2006; Fahlenbrach, 2009). In fact, in family firms control and ownership are connected because most owners or successors also appoint another family member as the CEO. According to prior literature it is argued that family members are more likely to identify with their business and are intrinsically motivated because they or their forefather built that firm and are more able to assert themselves (Anderson and Reeb, 2003; Adams et al., 2005; Villalonga and Amit, 2006; Fahlenbrach, 2009; Gao and Jain, 2011).

When the effect of founders and successors on firm performance and value has been investigated empirically, most prior studies base their analysis on samples of U.S. firms. These studies show that founder-CEOs positively 
affect the firm's market value (e.g. Anderson and Reeb, 2003; Villalonga and Amit, 2006; Fahlenbrach, 2009). The positive effect on the firm's market value is also existent when the founder only advises the management at board level (Li \& Srinivasan, 2011). Furthermore, when firms re-elect their founder as a director, firms benefit from higher profitability (Fahlenbrach, Minton, \& Pan, 2011). In contrast, Villalonga and Amit (2006) show that successor-CEOs in the second generation have a negative effect on the family firm's market value and the third or other generations do not have an effect on firm value at all. Due to findings provided by prior studies, Gao and Jain (2011) expect founder-CEOs to be more willing to take risks. Anderson and Reeb (2003) is the only study that shows both the founder-CEO and his or her successor has a positive effect on the firm's financial performance. In a study on small and medium-sized Danish firms, Bennedsen et al. (2008) show that firm size and family size are positively correlated and founder CEOs often offer board positions to their family members. In a Chinese study, Pan and Tian (2016) identify founder-CEOs as having a negative effect on the firm's market value in a sample of Chinese firms. They explain this effect based on China's less-well-pronounced shareholder protection and corporate governance, which enables family firms to use their status and power to follow their private interests only. In a survey, Mullins and Schoar (2016) are able to perceive a strong stakeholder orientation in firms with founder CEOs, while firms with professional CEOs seem to follow the interests of their stakeholders.

\subsection{Network Relationships}

Most studies define network relationships based on intersections between managers in terms of education or employment records as well as memberships in non-profit organizations (Hwang and Kim, 2009; Gaspar and Massa, 2011; Fracassi and Tate, 2012; Duchin and Sosyura, 2013; Faleye et al., 2014; Ishii and Xuan, 2014; Masulis and Reza, 2015; financial insitutions: Engelberg et al., 2012b). ${ }^{\text {vi }}$ Political relationships can be assigned to this category as well as and are measured based on managers' present or previous activeness in political or state-affiliated organization (Faccio et al., 2006; Fan et al., 2007; Goldman et al., 2009, 2013).

When analyzing network relationships, prior literature takes sociological concepts or homophily or the so-called "birds of a feather" concept into account (Hwang and Kim, 2009; Duchin and Sosyura 2013; Ishii and Xuan, 2014). These concepts enable group-building or group-thinking effects to be explained. Indeed, group heterogeneity is a relevant aspect, which Hambrick and Mason (1984) considered as an influencing characteristic in the context of the Upper Echelons Theory. Whether network relationships positively affect a firm's market value has been analyzed empirically. However, the direction of how work relationships affect a firm's success is not clearly predictable. On the one hand, network relationships contribute to reduced information asymmetries as well as agency conflicts, which positively affect the decision-making quality (Gaspar and Massa, 2011; Fracassi and Tate, 2012; Faleye et al., 2014). On the other hand, it is questionable whether CEOs or directors use their informational advantage in favor of the firm or whether they possibly use their informational advantage in order to follow their own interests (Gaspar and Massa, 2011; Cheung et al., 2013; financial insitutions: Engelberg et al., 2012b).

When a multidimensional firm allocates its internal capital, division managers who are well networked with the CEO receive more capital than managers without this relationship (Gaspar and Massa 2011; Duchin and Sosyura, 2013). This is in contrast to the bridge-building hypothesis by Xuan (2009). Duchin and Sosyura (2013) split their U.S. samples based on complexity and corporate governance quality. They find a positive effect on investment quality in highly complex firms but a negative effect in firms with less distinctive corporate governance indicators. Faleye et al. (2014) argue CEOs with well-developed external network relationships tend to take more risks because they may easily find a new employment in the case of failure.

A higher willingness to invest is also reflected in a higher quantity of acquisitions in firms with managers who exhibit an excellent network (Fracassi and Tate, 2012; Shue, 2013; Ishii and Xuan, 2014; El-Khatib et al., 2015). Prior studies show that internal relationships between CEOs and directors reduce the directors' independence and the monitoring effectiveness (Hwang and Kim 2009; Fracassi and Tate, 2012). In an event study, Fracassi and Tate (2012) show that the announcement of acquisition activities in firms with a well-developed network relationship between the CEO and director negatively affects cumulative abnormal returns (CAR). In line with this, Ishii and Xuan (2014) find that a well-developed external network between the acquisition parties' CEOs and directors negatively affects the CAR. However, it also increases the probability for a continuation of the CEO's term of office of the acquired firm. Cai and Sevilir (2012) identify a relationship based on the representation of directors at board level. For example, when both acquisition parties (acquiring and acquired firm) share a director this is called a "first-degree connection" while they call a relationship a ("second-degree connection") as soon as one director of each acquisition party serves at the board of a third firm. They argue their measurement is more precise as it also includes the professional level. In contrast to prior studies, Cai and Sevilir 
(2012) find a positive relationship between the announcement of acquisitions and CAR when there is a relationship between board members of the acquisition party. Another measurement of relationships is developed by El-Khatib et al. (2015), who argue that social relationships are manifold and hierarchic levels are highly relevant. They developed the so-called "Network Centrality" for CEOs (based on employment history), which provides information on a CEO's social position in his/her network, his or her skills to obtain information, to control others and to influence decisions. In line with Fracassi and Tate (2012), Ishii and Xuan (2014) and El-Khatib et al. (2015)'s results show that firms with high "centrality" CEOs exhibit negative CAR around acquisition announcements.

In comparison to the effect of the networks' relationship on a firm's investment, there is scant research on the effect on the firm's finance quality. Engelberg et al. (2012b) investigate the relationship between managers in banks and firms based on their employment history. They provide evidence that firms' managers with a well-developed network achieve lower interest rates as well as a reduced probability of credit clauses.

Khanna et al. (2015) suggest the number of managers that are appointed during the CEO's tenure ("appointment-based connectedness") as a new method to measure relationships, as this may also proxy for loyalty towards the CEO. In contrast to Engelberg et al. (2012b), Khanna et al.'s (2015) results indicate that network relationships between CEOs and directors increase the probability for financial fraud and decrease the chance of uncovering fraud activities.

When political relationships were analyzed, the U.S. capital market's reaction to the appointment of political connected directors is positive (Goldman et al., 2009). Such directors potentially dispose of a higher impact on certain regulations regarding governmental instructions. The latter can also be found in a subsequent study (Goldman et al., 2013). Similar results are presented in Faccio et al.'s (2006) cross-country study: firms that face the risk of not being a concern but have political connections are more likely to benefit from governmental transfer payments. Unlike most countries, Fan et al. (2007) show that political connections in Chinese firms are negatively related to the firm's performance, including share prices, revenues and return growth rates compared to IPOs with CEOs without political relationships.

\section{Discussion}

\subsection{Country and Industry Level Evidence}

As expected, most prior studies show significant relationships between managerial styles and firm outcomes which confirms our hypothesis. However, to our knowledge, research does not fully answer this question when it comes to evidence across countries. Indeed, most studies focus on the managerial style in U.S. samples, which provides great data availability for managers. However, it is questionable whether the results are generalizable to other country origins. For instance, the previous section shows that political network relationships are beneficial in the U.S. - this is not so in China. In addition, Ferris et al. (2013) provide evidence that there are more overconfident CEOs in countries with a primarily Christian character in religious and cultural terms. Hence, it is the question of whether political connections positively influence firms' market value in Europe just like in the U.S. Also, for most characteristics, especially overconfidence and optimism, private behavior and political conviction and network relationships, evidence on cultural differences is rare. However, there might also be information on CEOs' characteristics available in other countries. Hence, evidence for firms in other country origins is rare or missing.

Another important aspect is the generalizability of prior results at industry level. Most manager characteristics were analyzed independently from the industry the manager/CEO or firms operate in, except for Hirschleifer et al. (2012) or Gervais et al. (2011), who consider overconfidence in growth industries such as technology as value-creating. Even though most empirical studies control for industry fixed effects, they rarely show the differences across industries. For example, future research could analyze whether certain life or job experiences are more relevant in the service sector than in the production sector. In line with this, Kaplan et al. (2012) solely identify private equity firms and indicate the generalization of their results is limited. Thus, there are numerous potential open research questions regarding other board members or relationships against the background of different nations and industries.

\subsection{Board Members' Characteristics}

Furthermore, empirical evidence on the interaction between managers' characteristics in different board systems is scarce. Only six studies analyze management quality and network relationships within a management team. For example, existing evidence indicates that male and older CEOs are more overconfident than young female CEOs (Graham et al., 2013; Huang and Kisgen, 2013; financial insitutions: Ho et al. 2016). Nevertheless, the 
low number of studies on individual characteristics in management teams is surprising, as Hambrick and Mason (1984) assess the management team's composition as being highly relevant. Therefore, we suggest two different avenues for future research that may be relevant. First, under which circumstances are characteristics - or combination of characteristics - is a team beneficial for a firm? Are founder-CEOs with network relationships more successful in comparison to founder-CEOs without such resources? Are industry and financial experiences substitutable with certain network relationships?

In addition, more than half of all articles analyze CEOs' characteristics independently from other board members. Future research could consider board member's characteristics and interests at a more aggregated level. We follow the argumentation of Bernile et al. (2018) who state that more diverse boards adopt more persistent and less risky financial policies. In line with this, Pugliese et al. (2009) encourage future studies to examine the impact of institutional and context-specific factors on the (expected) contribution of boards to strategy. Accordingly, the following core questions could be addressed in the context of board compositions and board diversity. How does decision-making change when boards are highly diversified in terms of demographic characteristics, experiences and political interests? Which possible characteristics contribute favorable knowledge to the board? Overall, this literature review encourages researchers to focus on the interaction of at least two board member's characteristics and their interests at a more aggregated (board) level. Existing research does not sufficiently address these issues and we point out that manager fixed effects are worth investigating at a more aggregated level instead of focusing on one manager at the board.

\subsection{Theoretical and Methodological Issues}

Overall, prior literature leaves room for interpretation and various possible explanations for the observed results due to the use of different measurements of characteristics. Therefore, the identification of clear and meaningful indicators is necessary. Firms with older CEOs and a Republican orientation political-wise have lower debt-equity ratios, while financial expertise and overconfidence cause the opposite effect. Hence, it remains unclear which characteristic is the more significant one as soon as the manager disposes of financial knowledge but also reaches a certain age. In general, future research faces the challenge of considering existing literature and evidence on those characteristics in order to not omit potential interferences.

In addition, many possible characteristics are still unexplored. For example, previous literature exhibits research gaps on characteristics such as family status, parents' home, and ethnic or social origins. Besides these unaccounted for characteristics, some characteristics have been analyzed either for managers or directors. To our knowledge, the extent to which international experience is relevant for executive managers has not been analyzed. Finally, the discourse mentioned in the theory section is still up for debate, namely whether managers transfer their individual style to the firm they get hired by or whether they get hired or elected because of their existing individual characteristics. Custódio and Metzger (2014) and Kaplan et al. (2012) argue that some researchers try to exclude possible endogenous selection of CEOs but do not prove it. On the other hand, researchers trace back their results to an optimal match of firm and manager. Some firms appoint women for management positions due to their high empathy and the high portion of female customers in the micro finance industry (Mersland \& Strøm, 2009; Strøm et al., 2014; Tate \& Yang, 2015). Two studies address endogeneity and provide alternative approaches to analyze economic consequences of CEO turnovers. Fee et al. (2013) analyze the differential effect of exogenous events, such as the CEOs retirement due to health issues or endogenous CEO-changes (which are enforced by the firm or the board) on changes in corporate policies. When focusing acquisition returns, Golubov et al. (2015) identify a persistent fixed effect but do consider that results could occur due to CEO-changes or management quality indicators (Chemmanur et al., 2009). Some researchers point out a possible compromise and name two different interpretations. Graham et al. (2013) state that growth firms either hire overconfident managers or overconfident managers select themselves, as they are interested in growth firms. In their analysis, Cronqvist et al. (2012) investigate CEOs' private willingness to take on debt and find two different lines of interpretations. On the one hand, firms systematically replace CEOs with similar debt-equity preferences. This is the so-called endogenous "matching" between firms and manager. On the other hand, the economical effect between having private debt and the increased leverage at firm level is even higher, the weaker the corporate governance mechanism. The latter shows that managers' private style is transferable to the managerial style at firm level.

We suggest that managerial style research could benefit significantly if researchers were more open to (1) the possibility that managerial style and a firm's decisions are driven by both the management board and its composition of different individual managers that all exhibit different characteristics, and (2) the use of other methodological instruments, such as experiments, to answer important managerial-style questions that are difficult to answer with the archival data currently available. 


\title{
6. Conclusion
}

Over the last two decades, the interest in research on the relationship between various board members' characteristics and firms' strategic decisions and firm performance between boards of directors and strategy has grown significantly. In this study, we review articles in the area of managerial style and its effect on firms' strategic decisions and performance. In doing so, we focus on articles that were published in highly ranked and finance related journals between 2001 and 2016. In line with our hypothesis, most prior studies document a significant relationship between managerial style and firm outcome. This is also in line with Hambrick and Mason's (1984) Upper Echelons Theory. Apart from documenting the number and type of manager characteristics that have been analyzed so far we show methodological differences and weaknesses. When investigating the methodological approach, we follow Bertrand and Schoar (2003), who provide evidence that manager's individual influence (managerial style) on firms' outputs and outcomes is measurable and identifiable empirically via "manager fixed effects". This study reveals that, although the majority of existing empirical articles in this area refer to a managerial style, most studies do not control for these manager fixed effects. Albeit differences in methodology and measurements of characteristics cause ambiguous results, this paper exploits potential avenues for future research in the area of manager's characteristics. For instance, future researchers should focus on the interaction between at least two characteristics. For instance, how do overconfident managers with financial expert knowledge affect corporate decisions? Or, are industry and financial experiences substitutable with certain network relationships? How do managers with well-developed network relationships and high-risk aversion affect corporate outcomes? There may be also more individual characteristics, such as psychological but also skills, passions, or backgrounds and representation of other groups that could affect firm's strategic decisions. However, for some characteristics, the measurement or data availability is still an obstacle. Future research may also consider other methods to study manager fixed effects by implementing an experimental approach. Experiments enable researchers to isolate different effects via manipulation or post experimental questionnaires. Second, board member's characteristics should be also analyzed at a more aggregated level. In particular, interests and manager's characteristics may differ across board members and effects could be driven by board diversity, a phenomenon that has gained much attention in research but also in practice (Bernile et al., 2018; Pugliese et al., 2009). This review contributes to prior literature in providing insights on how empirical and analytical evidence contributes to the literature and illustrates the way in which the literature evolved, highlighting implications and suggesting avenues for future research.

\begin{abstract}
Notes
i Hereafter, we use the term "board", which refers to the management board in one-tier board systems. This board consists of both dependent and independent directors or executives and non-executives. Hereafter, we use the term "CEO" for the top most executive, "CFO" for the Chief financial officer and "director" for the non-executive director. In some cases, we use the term "manager", which refers to all board members.

ii For an overview regarding gender issues in accounting research over the period of 1994-2016, refer to a literature review by Khlif and Achek (2017).

iii To our knowledge, Jiang et al. (2016) is the only study that also uses a media indicator, which helps to quantify the manager's public reporting or news coverage.

iv Malmendier and Tate's (2005) argumentation on a CEO's portfolio behavior is based on Lambert et al. (1991) and Hall and Murphy (2002). We refer to Hirschleifer et al. (2012), Kolasinski and Li (2013) and Malmendier and Tate (2005) who do not consider alternative explanations or tax reasons for CEOs' portfolio compositions.

v Campbell et al. (2011) and Kolasinski and Li (2013) provide a similar approach that requires less data and thus enables research to include time frames after 1994.

vi Approaches may vary across prior studies. For instance, Ishii and Xuan (2014) do not consider non-profit-organizations and Fracassi and Tate (2012) do not require an active membership of non-profit-organizations.
\end{abstract}

\section{References}

Adams, M., \& Jiang, W. (2016). Do outside directors influence the financial performance of risk-trading firms? Evidence from the United Kingdom (UK) insurance industry. Journal of Banking \& Finance, 64, 36-51. https://doi.org/10.1016/j.jbankfin.2015.11.018

Adams, R. B., Almeida, H., \& Ferreira, D. (2005). Powerful CEOs and their impact on corporate performance. The Review of Financial Studies, 18(4), 1403-1432. https://doi.org/10.1093/rfs/hhi030 
Adams, R. B., \& Ferreira, D. (2009). Women in the boardroom and their impact on governance and performance. Journal of Financial Economics, 94(2), 291-309. https://doi.org/10.1016/j.jfineco.2008.10.007

Adam, T. R., Fernando, C. S., \& Golubeva, E. (2015). Managerial overconfidence and corporate risk management. Journal of Banking \& Finance, 60, 195-208. https://doi.org/10.1016/j.jbankfin.2015.07.013

Ahn, S., Jiraporn, P., \& Kim, Y. S. (2010). Multiple directorships and acquirer returns. Journal of Banking \& Finance, 34(9), 2011-2026. https://doi.org/10.1016/j.jbankfin.2010.01.009

Aktas, N., Bodt, E. de, Bollaert, H., \& Roll, R. (2016). CEO narcissism and the takeover process: from private initiation to deal completion. Journal of Financial and Quantitative Analysis, 51(1), 113-137. https://doi.org/10.1017/S0022109016000065

Aktas, N., Bodt, E. de, \& Roll, R. (2013). Learning from repetitive acquisitions: Evidence from the time between deals. Journal of Financial Economics, 108(1), 99-117. https://doi.org/10.1016/j.jfineco.2012.10.010

Anderson, R. C., \& Reeb, D. M. (2003). Founding-family ownership and firm performance: Evidence from the S\&P 500. The Journal of Finance, 58(3), 1301-1328. https://doi.org/10.1111/1540-6261.00567

Andriosopoulos, D., Andriosopoulos, K., \& Hoque, H. (2013). Information disclosure, CEO overconfidence, and share buyback completion rates. Journal of Banking \& Finance, 37(12), 5486-5499. https://doi.org/10.2139/ssrn.2023051

Banerjee, S., Humphery-Jenner, M., \& Nanda, V. (2015). Restraining overconfident CEOs through Improved Governance: Evidence from the Sarbanes-Oxley Act. The Review of Financial Studies, 28(10), 2812-2858. https://doi.org/10.1093/rfs/hhv034

Barber, B. M., \& Odean, T. (2001). Boys will be boys: gender, overconfidence, and common stock investment. The Quarterly Journal of Economics, 116(1), 261-292. https://doi.org/10.1162/003355301556400

Benmelech, E., \& Frydman, C. (2015). Military CEOs. Journal of Financial Economics, (Volume 117, Issue 1), 43-59.

Bennedsen, M., Kongsted, H. C., \& Nielsen, K. M. (2008). The causal effect of board size in the performance of small and medium-sized firms. Journal of Banking \& Finance, 32(6), 1098-1109.

Bernile, G., Bhagwat, V., \& Yonker, S. (2018). Board diversity, firm risk, and corporate policies. Journal of Financial Economics, 127(3), 588-612. https://doi.org/10.1016/j.jfineco.2017.12.009

Bertrand, M., \& Schoar, A. (2003). Managing with style. The effect of managers on firm policies. Quarterly Journal of Economics, (Volume 68, Issue 4), 1169-1208.

Bhagat, S., Bolton, B., \& Subramanian, A. (2011). Manager characteristics and capital structure: Theory and evidence. Journal of Financial and Quantitative Analysis, 46(6), 1581-1627. https://doi.org/10.1017/S0022109011000482

Biggerstaff, L., Cicero, D. C., \& Puckett, A. (2015). Suspect CEOs, unethical culture, and corporate misbehavior. Journal of Financial Economics, 117(1), 98-121. https://doi.org/10.1016/j.jfineco.2014.12.001

Bloom, N., \& van Reenen, J. (2007). Measuring and explaining management practices across firms and countries. The Quarterly Journal of Economics, 122(4), 1351-1408. https://doi.org/10.1162/qjec.2007.122.4.1351

Bofinger, P. (2011). Grundzüge der Volkswirtschaftslehre: Eine Einführung in die Wissenschaft von Märkten (3., aktualisierte Aufl.). München: Pearson Studium.

Bouwman, C. H. S. (2014). Managerial optimism and earnings smoothing. Journal of Banking \& Finance, 41, 283-303. https://doi.org/10.1016/j.jbankfin.2013.12.019

Cain, M. D., \& McKeon, S. B. (2016). CEO personal risk-taking and corporate policies. Journal of Financial and Quantitative Analysis, 51(1), 139-164. https://doi.org/10.1017/S0022109016000041

Cai, Y., \& Sevilir, M. (2012). Board connections and M\&A transactions. Journal of Financial Economics, 103(2), 327-349.

Campbell, T. C., Gallmeyer, M., Johnson, S. A., Rutherford, J., \& Stanley, B. W. (2011). CEO optimism and forced turnover. Journal of Financial Economics, 101(3), 695-712.

https://doi.org/10.1016/j.jfineco.2011.03.004

Cashman, G. D., Gillan, S. L., \& Jun, C. (2012). Going overboard? On busy directors and firm value. Journal of 
Banking \& Finance, 36(12), 3248-3259. https://doi.org/10.1016/j.jbankfin.2012.07.003

Celikyurt, U., Sevilir, M., \& Shivdasani, A. (2014). Venture capitalists on boards of mature public firms. The Review of Financial Studies, 27(1), 57-101. https://doi.org/10.1093/rfs/hhs096

Chemmanur, T. J., \& Paeglis, I. (2005). Management quality, certification, and initial public offerings. Journal of Financial Economics, 76(2), 331-368. https://doi.org/10.1016/j.jfineco.2004.10.001

Chemmanur, T. J., Paeglis, I., \& Simonyan, K. (2009). Management quality, financial and investment policies, and asymmetric information. Journal of Financial and Quantitative Analysis, 44(5), 1045-1079. https://doi.org/10.1017/S0022109009990299

Cheung, Y.-L., Chung, C.-W., Tan, W., \& Wang, W. (2013). Connected board of directors: A blessing or a curse? Journal of Banking \& Finance, 37(8), 3227-3242. https://doi.org/10.1016/j.jbankfin.2013.03.001

Cornelli, F., Kominek, Z., \& Ljungqvist, A. (2013). Monitoring managers: Does It matter? The Journal of Finance, 68(2), 431-481. https://doi.org/10.1111/jofi.12004

Cronqvist, H., Makhija, A. K., \& Yonker, S. E. (2012). Behavioral consistency in corporate finance: CEO personal and corporate leverage. Journal of Financial Economics, 103(1), 20-40. https://doi.org/10.1016/j.jfineco.2011.08.005

Custódio, C., \& Metzger, D. (2013). How do CEOs matter? The effect of industry expertise on acquisition returns. The Review of Financial Studies, 26(8), 2007-2047. https://doi.org/10.1093/rfs/hht032

Custódio, C., \& Metzger, D. (2014). Financial expert CEOs: CEO's work experience and firm's financial policies. Journal of Financial Economics, 114(1), 125-154. https://doi.org/10.1016/j.jfineco.2014.06.002

Dass, N., Omesh, K., Nanda, V., Onal, B., \& Wang, J. (2014). Board Expertise: Do directors from related industries help bridge the information gap? The Review of Financial Studies, 27(5), 1533-1592. https://doi.org/10.1093/rfs/hht071

Davidson, R., Dey, A., \& Smith, A. (2015). Executives' "off-the-job” behavior, corporate culture, and financial reporting risk. Journal of Financial Economics, 117(1), 5-28.

Deshmukh, S., Goel, A. M., \& Howe, K. M. (2013). CEO overconfidence and dividend policy. Journal of Financial Intermediation, 22(3), 440-463. https://doi.org/10.1016/j.jfi.2013.02.003

Di Giuli, A., \& Kostovetsky, L. (2014). Are red or blue companies more likely to go green? Politics and corporate social responsibility. Journal of Financial Economics, 111(1), 158-180. https://doi.org/10.1016/j.jfineco.2013.10.002

Dittmar, A., \& Duchin, R. (2016). Looking in the rearview mirror: The effect of managers' professional experience on corporate financial policy. The Review of Financial Studies, 29(3), 565-602. https://doi.org/10.1093/rfs/hhv051

Duchin, R., \& Sosyura, D. (2013). Divisional managers and internal capital markets. The Journal of Finance, 68(2), 387-429. https://doi.org/10.1111/jofi.12003

El-Khatib, R., Fogel, K., Jandik, \& Tomas. (2015). CEO network centrality and merger performance. Journal of Financial Economics, 116(2), 349-382. https://doi.org/10.1016/j.jfineco.2015.01.001

Elyasiani, E., \& Zhang, L. (2015). Bank holding company performance, risk, and "busy" board of directors. Journal of Banking \& Finance, 60, 239-251. https://doi.org/10.1016/j.jbankfin.2015.08.022

Engelberg, J., Gao, P., \& Parsons, C. A. (2012a). Friends with money. Journal of Financial Economics, 103(1), 169-188. https://doi.org/10.1016/j.jfineco.2011.08.003

Engelberg, J., Gao, P., \& Parsons, C. A. (2012b). The price of a CEO's rolodex. The Review of Financial Studies, 26(1), 79-114. https://doi.org/10.1093/rfs/hhs114

Faccio, M., Masulis, R. W., \& McConnell, J. H. (2006). Political connections and corporate bailouts. The Journal of Finance, 61(6), 2597-2635. https://doi.org/10.1111/j.1540-6261.2006.01000.x

Fahlenbrach, R. (2009). Founder-CEOs, investment decisions, and stock market performance. Journal of Financial and Quantitative Analysis, 44(2), 439-466. https://doi.org/10.1017/S0022109009090139

Fahlenbrach, R., Minton, B. A., \& Pan, C. H. (2011). Former CEO directors: Lingering CEOs or valuable resources? The Review of Financial Studies, 24(10), 3486-3518. https://doi.org/10.1093/rfs/hhr056 
Falato, A., Kadyrzhanova, D., \& Lel, U. (2014). Distracted directors: Does board busyness hurt shareholder value? Journal of Financial Economics, 113(3), 404-426. https://doi.org/10.1016/j.jfineco.2014.05.005

Faleye, O., Kovacs, T., \& Venkateswaran, A. (2014). Do better-connected CEOs innovate more? Journal of Financial and Quantitative Analysis, 49(5), 1201-1225. https://doi.org/10.1017/S0022109014000714

Fama, E. F., \& Jensen, M. C. (1983). Separation of Ownership and Control. Journal of Law and Economics, 26(2), 301-325.

Fan, J. P. H., Wong, T. J., \& Zhang, T. (2007). Politically connected CEOs, corporate governance, and Post-IPO performance of China's newly partially privatized firms. Journal of Financial Economics, 84(2), 330-357. https://doi.org/10.1016/j.jfineco.2006.03.008

Fee, C. E., Hadlock, C. J., \& Pierce, J. R. (2013). Managers with and without style: Evidence using exogenous variation. The Review of Financial Studies, 26, 567-601. https://doi.org/10.1093/rfs/hhs131

Ferris, S. P., Jagannathan, M., \& Pritchard, A. C. (2003). Too busy to mind the business? monitoring by directors with multiple board appointments. The Journal of Finance, 58(3), 1087-1111. https://doi.org/10.1111/1540-6261.00559

Ferris, S. P., Jayaraman, N., \& Sabherwal, S. (2013). CEO overconfidence and international merger and acquisition activity. Journal of Financial and Quantitative Analysis, 48(1), 137-164. https://doi.org/10.1017/S0022109013000069

Fich, E. M., \& Shivdasani, A. (2006). Are Busy Boards Effective Monitors? The Journal of Finance, 61(2), 689-724. https://doi.org/10.1111/j.1540-6261.2006.00852.x

Field, L., Lowry, M., \& Mkrtchyan, A. (2013). Are busy boards detrimental? Journal of Financial Economics, 109(2), 63-82. https://doi.org/10.1016/j.jfineco.2013.02.004

Fracassi, C., \& Tate, G. (2012). External networking and internal firm governance. The Journal of Finance, 67(1), 153-194. https://doi.org/10.1111/j.1540-6261.2011.01706.x

Gao, N., \& Jain, B. A. (2011). Founder CEO management and the long-run investment performance of IPO firms. Journal of Banking \& Finance, 35(7), 1669-1682. https://doi.org/10.1016/j.jbankfin.2010.11.008

García-Meca, E., García-Sánchez, I.-M., \& Martínez-Ferrero, J. (2015). Board diversity and its effects on bank performance: An international analysis. Journal of Banking \& Finance, 53, 202-214. https://doi.org/10.1016/j.jbankfin.2014.12.002

Gaspar, J.-M., \& Massa, M. (2011). The role of commonality between CEO and divisional managers in internal capital markets. Journal of Financial and Quantitative Analysis, 46(6), 841-869. https://doi.org/10.1017/S0022109011000111

Gervais, S., Heaton, J. B., \& Odean, T. (2011). Overconfidence, compensation contracts, and capital budgeting. The Journal of Finance, 66(5), 1735-1777. https://doi.org/10.1111/j.1540-6261.2011.01686.x

Giannetti, M., Liao, G., \& Yu, X. (2015). The brain gain of corporate boards: Evidence from China. The Journal of Finance, 70(4), 1629-1682. https://doi.org/https://doi.org/10.1111/jofi.12198

Goel, A. M., \& Thakor, A. v. (2008). Overconfidence, CEO selection, and corporate governance. The Journal of Finance, 63(6), 2737-2784. https://doi.org/https://doi.org/10.1111/j.1540-6261.2008.01412.x

Goldman, E., Rocholl, J., \& So, J. (2009). Do politically connected boards affect firm value? The Review of Financial Studies, 22(6), 2331-2360. https://doi.org/10.1093/rfs/hhn088

Goldman, E., Rocholl, J., \& So, J. (2013). Politically connected boards of directors and the allocation of procurement contracts. Review of Finance, 17(5), 1617-1648. https://doi.org/10.1093/rof/rfs039

Golubov, A., Yawson, A., \& Zhang, H. (2015). Extraordinary acquirers. Journal of Financial Economics, 116, 314-330. https://doi.org/10.1016/j.jfineco.2015.02.005

Graham, J. R., \& Harvey, C. R. (2001). The theory and practice of corporate finance: evidence from the field. Journal of Financial Economics, 60(3), 187-243. https://doi.org/10.1016/S0304-405X(01)00044-7

Graham, J. R., Harvey, C. R., \& Puri, M. (2013). Managerial attitudes and corporate actions. Journal of Financial Economics, 109(1), 103-121.

Graham, J. R., Harvey, C. R., \& Puri, M. (2015). Capital allocation and delegation of decision-making authority 
within firms. Journal of Financial Economics, 115(3), 449-470.

https://doi.org/10.1016/j.jfineco.2014.10.011

Graham, J. R., Li, S., \& Qiu, J. (2012). Managerial attributes and executive compensation. The Review of Financial Studies, 25(1), 144-186. https://doi.org/https://doi.org/10.1016/j.jfineco.2013.01.010

Güner, A. B., Malmendier, U., \& Tate, G. (2008). Financial expertise of directors. Journal of Financial Economics, 88(2), 323-354. https://doi.org/10.1016/j.jfineco.2007.05.009

Hackbarth, D. (2008). Managerial traits and capital structure decisions. Journal of Financial and Quantitative Analysis, 43(4), 843-882. https://doi.org/10.1017/S002210900001437X

Hall, B. J., \& Murphy, K. J. (2002). Stock options for undiversified executives. Journal of Accounting and Economics, 33, 3-42. https://doi.org/10.1016/S0165-4101(01)00050-7

Hambrick, D. C. (2007). Upper Echelons Theory: An Update. The Academy of Management Review, (Volume 32, Issue 2), 334-343.

Hambrick, D. C., \& Mason, P. A. (1984). Upper echelons: The organization as a reflection of its top managers. The Academy of Management Review, 9(2), 193-206. https://doi.org/10.5465/amr.1984.4277628

Hirschleifer, D., Low, A., \& Teoh, S. H. (2012). Are overconfident CEOs better innovators? The Journal of Finance, 67(4), 1457-1498. https://doi.org/10.1111/j.1540-6261.2012.01753.x

Ho, P.-H., Huang, C.-W., Lin, C.-Y., \& Yen, J.-F. (2016). CEO overconfidence and financial crisis: Evidence from bank lending and leverage. Journal of Financial Economics, 120(1), 194-209. https://doi.org/10.1016/j.jfineco.2015.04.007

Huang, J., \& Kisgen, D. J. (2013). Gender and corporate finance: Are male executives overconfident relative to female executives? Journal of Financial Economics, 108(3), 822-839. https://doi.org/10.1016/j.jfineco.2012.12.005

Huang, S. (2014). Managerial expertise, corporate decisions and firm value: Evidence from corporate refocusing. Journal of Financial Intermediation, 23(3), 348-375. https://doi.org/10.1016/j.jfi.2014.04.003

Hubbard, R. G. (1998). Capital-market imperfections and investment. Journal of Economic Literature, 36(1), 193-225.

Hutton, I., Jiang, D., \& Kumar, A. (2014). Corporate policies of republican managers. Journal of Financial and Quantitative Analysis, 49(5), 1279-1310. https://doi.org/10.1017/S0022109014000702

Hwang, B.-H., \& Kim, S. (2009). It pays to have friends. Journal of Financial Economics, 93(1), 138-158. https://doi.org/10.1016/j.jfineco.2008.07.005

Ishii, J., \& Xuan, Y. (2014). Acquirer-target social ties and merger outcomes. Journal of Financial Economics, 112(3), 344-363. https://doi.org/10.1016/j.jfineco.2014.02.007

Jacobsen, S. (2014). The death of the deal: Are withdrawn acquisition deals informative of CEO quality? Journal of Financial Economics, 114(1), 54-83. https://doi.org/10.1016/j.jfineco.2014.05.011

Jenter, D., \& Lewellen, K. (2015). CEO preferences and acquisitions. The Journal of Finance, 70(6), 2813-2852. https://doi.org/10.1111/jofi.12283

Jiang, W., Wan, H., \& Zhao, S. (2016). Reputation concerns of independent directors: Evidence from individual director voting. The Review of Financial Studies, 29(3), 655-696. https://doi.org/10.1093/rfs/hhv125

Jiraporn, P., Singh, M., \& Lee, C. I. (2009). Ineffective corporate governance: Director busyness and board committee memberships. Journal of Banking \& Finance, 33(5), 819-828. https://doi.org/10.1016/j.jbankfin.2008.09.020

Kaplan, S. N., Klebanov, M. M., \& Sorensen, M. (2012). Which CEO characteristics and abilities matter? The Journal of Finance, 67(3), 973-1007. https://doi.org/10.1111/j.1540-6261.2012.01739.x

Kauko, K. (2009). Managers and efficiency in banking. Journal of Banking \& Finance, 33(3), 546-556. https://doi.org/10.1016/j.jbankfin.2008.09.007

Khanna, V., Kim, E. H., \& Lu, Y. (2015). CEO connectedness and corporate fraud. The Journal of Finance, 70(3), 1203-1252. https://doi.org/10.1111/jofi.12243

Khlif, H., \& Achek, I. (2017). Gender in accounting research: a review. Managerial Auditing Journal, 32(6). 
https://doi.org/10.1108/MAJ-02-2016-1319

Kim, Y. H. (Andy). (2013). Self attribution bias of the CEO: Evidence from CEO interviews on CNBC. Journal of Banking \& Finance, 37(7), 2472-2489. https://doi.org/10.1016/j.jbankfin.2013.02.008

Kolasinski, A. C., \& Li, X. (2013). Can strong boards and trading their own firm's stock help CEOs make better decisions? Evidence from acquisitions by overconfident CEOs. Journal of Financial and Quantitative Analysis, 48(4), 1173-1206. https://doi.org/10.1017/S0022109013000392

Lambert, R. A., Larcker, D. F., \& Verrecchi, R. E. (1991). Portfolio considerations in valuing executive compensation. Journal of Accounting Research, 29, 129-149. https://doi.org/10.2307/2491032

Lee, J., Lee, K. J., \& Nagarajan, N. J. (2014). Birds of a feather: Value implications of political alignment between top management and directors. Journal of Financial Economics, 112(2), 232-250. https://doi.org/10.1016/j.jfineco.2014.02.004

Lemmon, M., Roberts, M., \& Zender, J. (2008). Back to the beginning: Persistence and the cross-sectional distribution of capital structure. The Journal of Finance, 63, 1575-1608. https://doi.org/10.1111/j.1540-6261.2008.01369.x

Li, F., \& Srinivasan, S. (2011). Corporate governance when founders are directors. Journal of Financial Economics, 102(2), 454-469. https://doi.org/10.1016/j.jfineco.2010.11.006

Lin, Z., Song, B. Y., \& Tian, Z. (2016). Does director-level reputation matter? Evidence from bank loan contracting. Journal of Banking \& Finance, 70, 160-176. https://doi.org/10.1016/j.jbankfin.2016.04.021

Malmendier, U., \& Tate, G. (2005). CEO overconfidence and corporate investment. The Journal of Finance, 60(6), 2661-2700. https://doi.org/10.1111/j.1540-6261.2005.00813.x

Malmendier, U., \& Tate, G. (2008). Who makes acquisitions? CEO overconfidence and the market's reaction. Journal of Financial Economics, 89(1), 20-43. https://doi.org/10.1016/j.jfineco.2007.07.002

Malmendier, U., Tate, G., \& Yan, J. (2011). Overconfidence and early-life experiences: The effect of managerial traits on corporate financial policies. The Journal of Finance, 66(5), 1687-1733. https://doi.org/10.1111/j.1540-6261.2005.00813.x

Masulis, R. W., \& Reza, S. W. (2015). Agency problems of corporate philanthropy. The Review of Financial Studies, 28(2), 592-636. https://doi.org/10.1093/rfs/hhu082

Mersland, R., \& Strøm, R. Ø. (2009). Performance and governance in microfinance institutions. Journal of Banking \& Finance, 33(4), 662-669. https://doi.org/10.1016/j.jbankfin.2008.11.009

Miller, M. H. (1977). Debt and taxes. The Journal of Finance, 32, 261-275. https://doi.org/10.1111/j.1540-6261.1977.tb03267.x

Minton, B. A., Taillard, J. P., \& Williamson, R. (2014). Financial expertise of the board, risk taking, and performance: evidence from bank holding companies. Journal of Financial and Quantitative Analysis, 49(2), 351-380. https://doi.org/10.1017/S0022109014000283

Mironov, M. (2015). Should one hire a corrupt CEO in a corrupt country? Journal of Financial Economics, 117(1), 29-42. https://doi.org/10.1016/j.jfineco.2014.03.002

Mullins, W., \& Schoar, A. (2016). How do CEOs see their roles? Management philosophies and styles in family and non-family firms. Journal of Financial Economics, 119(1), 24-43.

https://doi.org/10.1016/j.jfineco.2015.08.011

Myers, S. C., \& Majluf, N. S. (1984). Corporate financing and investment decisions when firms have information that investors do not have. Journal of Financial Economics, 13(2), 187-221. https://doi.org/https://doi.org/10.1016/0304-405X(84)90023-0

Oxelheim, L., \& Randøy, T. (2003). The impact of foreign board membership on firm value. Journal of Banking \& Finance, 27(12), 2369-2392. https://doi.org/10.1016/S0378-4266(02)00395-3

Pan, X., \& Tian, G. G. (2016). Family control and loan collateral: Evidence from China. Journal of Banking \& Finance, 67, 53-68. https://doi.org/10.1016/j.jbankfin.2016.02.003

Pan, Y., Wang, T. Y., \& Weisbach, M. S. (2016). CEO investment cycles. The Review of Financial Studies, (Volume 29, Issue 11), 2955-2999. 
Pan, Y., Wang, Y., \& Weisbach, M. S. (2015). Learning about CEO ability and stock return volatility. The Review of Financial Studies, 28(6), 1623-1666. https://doi.org/10.1093/rfs/hhv014

Perry, T., \& Peyer, U. (2005). Board seat accumulation by executives: A shareholder's perspective. The Journal of Finance, 60(4), 2083-2123. https://doi.org/10.1111/j.1540-6261.2005.00788.x

Pugliese, A., Bezemer, P.-J., Zattoni, A., Huse, M., Van den Bosch, F. A., \& Volberda, H. W. (2009). Boards of directors' contribution to strategy: A literature review and research agenda. Corporate Governance: An International Review, 17(3), 292-306. https://doi.org/10.1111/j.1467-8683.2009.00740.x

Rahaman, M. M., \& Zaman, A. A. (2013). Management quality and the cost of debt: Does management matter to lenders? Journal of Banking \& Finance, 37(3), 854-874. https://doi.org/10.1016/j.jbankfin.2012.10.011

Rousseau, P. L., \& Stroup, C. (2015). Director histories and the pattern of acquisitions. Journal of Financial and Quantitative Analysis, 50(4), 671-698. https://doi.org/10.1017/S0022109015000289

Seglen, P. O. (1994). Causal relationship between article citedness and journal impact. Journal of the American Society for Information Science, 45(1), 1. https://doi.org/10.1002/(SICI)1097-4571(199401)45:1<1::AID-ASI1>3.0.CO;2-Y

Shivdasani, A., \& Yermack, D. (1999). CEO involvement in the selection of new board members: An empirical analysis. The Journal of Finance, 54(5), 1829-1853. https://doi.org/10.1111/0022-1082.00168

Shue, K. (2013). Executive networks and firm policies: Evidence from the random assignment of MBA peers. The Review of Financial Studies, 26(6), 1401-1442. https://doi.org/10.1093/rfs/hht019

Stein, J. C. (2003). Agency, information and corporate investment. Handbook of the Economics of Finance, 1, 111-165. https://doi.org/10.1016/S1574-0102(03)01006-9

Strøm, R. Ø., D’Espallier, B., \& Mersland, R. (2014). Female leadership, performance, and governance in microfinance institutions. Journal of Banking \& Finance, 42, 60-75. https://doi.org/10.1016/j.jbankfin.2014.01.014

Tate, G., \& Yang, L. (2015). Female leadership and gender equity: Evidence from plant closure. Journal of Financial Economics, 117(1), 77-97. https://doi.org/10.1016/j.jfineco.2014.01.004

Thaler, R. H. (2000). From homo economicus to homo sapiens. The Journal of Economic Perspectives, 14(1), 133-141. https://doi.org/10.1257/jep.14.1.133

Thaler, R. H. (2017). Richard H. Thaler - Banquet Speech. Retrieved from https://www.nobelprize.org/nobel_prizes/economic-sciences/laureates/2017/thaler-speech.html

Villalonga, B., \& Amit, R. (2006). How do family ownership, control and management affect firm value? Journal of Financial Economics, 80(2), 385-417. https://doi.org/10.1016/j.jfineco.2004.12.005

Wang, C., Xie, F., \& Zhu, M. (2015). Industry expertise of independent directors and board monitoring. Journal of Financial and Quantitative Analysis, 50(5), 929-962. https://doi.org/10.1017/S0022109015000459

Xuan, Y. (2009). Empire-building or bridge-building? Evidence from new CEOs' internal capital allocation decisions. The Review of Financial Studies, 22(12), 4919-4948. https://doi.org/10.1093/rfs/hhp030

Yim, S. (2013). The acquisitiveness of youth: CEO age and acquisition behavior. Journal of Financial Economics, 108(1), 250-273. https://doi.org/10.1016/j.jfineco.2012.11.003

\section{Copyrights}

Copyright for this article is retained by the author(s), with first publication rights granted to the journal.

This is an open-access article distributed under the terms and conditions of the Creative Commons Attribution license (http://creativecommons.org/licenses/by/4.0/). 